5 Diacon AH, Dawson R, von Groote-Bidlingmaier F, et al. 14-day bactericidal activity of PA-824, bedaquiline, pyrazinamide, and moxifloxacin combinations: a randomised trial. Lancet 2012; 380: 986-993.
6 Zumla A, Blasi F, Raviglione M. Rational use of anti-tuberculosis drugs in the EU: better patient care and less drug resistance. Eur Respir J 2012; 39: 802-804.

DOI: 10.1183/09031936.00112612

\title{
Adjusting diffusing capacity of the lung for carbon monoxide for haemoglobin level
}

\section{To the Editor:}

The joint statements on lung function testing by the American Thoracic Society (ATS)/European Respiratory Society (ERS) Task Force provided useful recommendations for standardisation of the tests in daily practice [1]. However, the equations for adjusting diffusing capacity of the lung for carbon monoxide $(\mathrm{DL}, \mathrm{CO})$ for the haemoglobin $(\mathrm{Hb})$ level (equations 13 and 14 in the original document) may be confusing [1]. In daily clinical practice, instead of changing the predicted reference value, we tend to adjust the observed $D L, C O$ value as if the patient had a normal $\mathrm{Hb}$ level [2-4]. Therefore, as suggested by most guidelines [2, 4], we suggest new equations for adjustment, as shown in table 1 .

It is well known that anaemia decreases observed $D L, C O$ by decreasing the area for diffusion due to a reduction in pulmonary capillary haemoglobin [1-4]. For example, in our suggested equation for adult males and adolescents, a $\mathrm{Hb}$ level $<14.6 \mathrm{~g} \cdot \mathrm{dL}^{-1}$ makes $(10.22+\mathrm{Hb}) /(1.7 \times \mathrm{Hb})>1$, making $D \mathrm{~L}, \mathrm{CO}_{\text {adjusted for } \mathrm{Hb}}>\mathrm{DL}, \mathrm{CO}_{\text {observed }}$ to eliminate the effect of anaemia. This adjustment makes DL,CO more standardised for assessing pulmonary conditions.

As the joints statements by the ATS/ERS Task Force are widely used as a guide for standardisation of clinical practice, we believe that clarifying this point is important.

\section{Ming-Ju Tsai*,\#, ${ }^{*},+$, Chih-Jen Yang ${ }^{*},+,+$, , Jhi-Jhu Hwang ${ }^{*, f}$, and Ming-Shyan Huang ${ }^{*,+,}$}

*Division of Pulmonary and Critical Care Medicine, Dept of Internal Medicine, Kaohsiung Medical University Hospital, Kaohsiung Medical University, "Dept of Internal Medicine, Kaohsiung Municipal HsiaoKang Hospital, Kaohsiung
Medical University, "Dept of Internal Medicine, Kaohsiung Municipal TaTung Hospital, Kaohsiung Medical University, ${ }^{+}$Graduate Institute of Medicine, School of Medicine, College of Medicine, Kaohsiung Medical University, ${ }^{\S}$ Dept of Internal Medicine, School of Medicine, College of Medicine, Kaohsiung Medical University, and ${ }^{f}$ Dept of Respiratory Therapy, College of Medicine, Kaohsiung Medical University, Kaohsiung, Taiwan.

Correspondence: M-S. Huang, Division of Pulmonary and Critical Care Medicine, Dept of Internal Medicine, Kaohsiung Medical University Hospital, Kaohsiung Medical University, No. 100 Tzyou 1st Road, Kaohsiung 807, Taiwan. E-mail: shyang@cc.kmu.edu.tw

Statement of Interest: None declared.

\section{REFERENCES}

1 Macintyre N, Crapo RO, Viegi G, et al. Standardisation of the singlebreath determination of carbon monoxide uptake in the lung. Eur Respir J 2005; 26: 720-735.

2 American Thoracic Society. Single-breath carbon monoxide diffusing capacity (transfer factor). Recommendations for a standard technique - 1995 update. Am J Respir Crit Care Med 1995; 152: 2185-2198.

3 Marrades RM, Diaz O, Roca J, et al. Adjustment of DL,CO for hemoglobin concentration. Am J Respir Crit Care Med 1997; 155: 236-241.

4 American Association for Respiratory Care. AARC clinical practice guideline: single-breath carbon monoxide diffusing capacity, 1999 update. Respir Care 1999; 44: 539-546.

DOI: 10.1183/09031936.00152212

TABLE 1 Summary of the suggested changes

Original equations (to adjust predicted value) [1]

$D \mathrm{~L}, \mathrm{CO}_{\text {predicted for } \mathrm{Hb}}=D \mathrm{~L}, \mathrm{CO}_{\text {predicted }} \times(1.7 \times \mathrm{Hb}) /(10.22+\mathrm{Hb})$

$\mathrm{DL}, \mathrm{CO}_{\text {predicted for } \mathrm{Hb}}=\mathrm{DL}, \mathrm{CO}_{\text {predicted }} \times(1.7 \times \mathrm{Hb}) /(9.38+\mathrm{Hb})$
Suggested equations (to adjust observed value)

$D \mathrm{~L}, \mathrm{CO}_{\text {adjusted for } \mathrm{HL}}=D \mathrm{~L}, \mathrm{CO}_{\text {observed }} \times(10.22+\mathrm{Hb}) /(1.7 \times \mathrm{Hb})$

$D \mathrm{~L}, \mathrm{CO}_{\text {adjusted for } \mathrm{Hb}}=\mathrm{DL}, \mathrm{CO}_{\text {observed }} \times(9.38+\mathrm{Hb}) /(1.7 \times \mathrm{Hb})$
For adult males and adolescents For adult females and children $<15$ yrs of age

DL,CO: diffusing capacity of the lung for carbon monoxide; $\mathrm{Hb}$ : haemoglobin. 